\title{
The effect of motion games on improving the psychomotor and intellectual performance of children with autism spectrum disorder and intellectual disabilities
}

\author{
MOCANU George-Dănuț ${ }^{1}$, GAVRILA Udrea Maria ${ }^{2}$
}

Editor: Constantin Munteanu, Romanian Association of Balneology, office@bioclima.ro

Reviewers: Silisteanu Sinziana Calina and Gabriela Dogaru

*Corresponding author: George -Dănuț Mocanu , email: george.mocanu@ugal.ro

1 "Dunărea de Jos" University, Faculty of Physical Education and Sports, 63-65 Gării Street, Galaţi, Romania

2 “Spiru Haret” Secondary School Țăndărei

\begin{abstract}
Introduction. Depressive states and anxiety are common symptoms of children with autism spectrum disorder (ASD). The persons with intellectual disabilities show problems related to the development of basic motor skills, having learning problems compared to normal ones, imbalances between the processes of arousal and inhibition, limited motor ability, difficult understanding of language and motor tasks, difficult concentration, mechanical assimilation etc.

Objectives. The study analyzes the effectiveness of structures and motion games, applied in specific activities for children with intellectual disabilities (ID) and autism spectrum disorders (ASD).

Material and Methods. The research involved an experimental group of 5 children with one of these disabilities or their combination (age 10-11 years), included in a training process at the Ion Teodorescu Special Vocational School in Slobozia / Ialomița / Romania and comparing their results with a control group (6 normal children, with an average age of 10 years), between 20.09.2020-10.03.2021. The assessment of the level of psychomotor and intellectual development was made by the Cutout Test, the Cohs Cube Test (light task configurations) and an Attention Flexibility Test (movement to the corners of the room/field depending on the assigned color, counting successful attempts and mistakes).

Results and discussion. The obtained results confirm the working hypothesis, so the use of the structures and games proposed in the program contributes to a significant improvement of the psychomotor and intellectual performances of students with intellectual disabilities and autism spectrum.

Conclusion. espite all these improvements, they cannot approach or equal the reference values of children without problems, falling into the same age category.
\end{abstract}

Keywords: psychomotor skills, adapted physical activities, recovery, children, learning disabilities,

\section{INTRODUCTION}

The persons with intellectual disabilities show problems related to the development of basic motor skills, having learning problems compared to normal ones, imbalances between the processes of arousal and inhibition, limited motor ability, difficult understanding of language and motor tasks, difficult concentration, mechanical assimilation etc. The motivation and the involvement in the effort are limited, being often rejected by those of their age, so limited motor performance. It is necessary to adapt teaching strategies, facilitate access to physical effort, remove social barriers (1). Physical activities must be objectified according to the individual needs of the participants and their disabilities; the volume of information that can be processed is smaller and requires more repetitions (2). Adolescents with health-compromising eating behaviors (HCEBs) as well as those with high BMI values have lower self- esteem and poorer body image, especially among girls (3).

Depressive states and anxiety are common symptoms of children with autism spectrum disorder (ASD), according (4). Other authors indicate other symptoms: difficult communication, hyperactivity, destruction of toys, aggression and self-aggression, sleep and eating disorders, poor social interaction, sensory sensitivity etc. (5).

A synthesis of specialized works that address the problem of autism and motor interventions on fundamental movement skills for young people is made by $(6,7)$. For children and young people, physical activity interventions have optimized the balance and fundamental movement skills, but those with disabilities are lagging behind those with normal development. The effectiveness of sensory physical exercise in improving fine and gross motor 
skills in children with learning disabilities is reported by (8). In addition to physical exercise, the type of bio-climate (exciting, sedative, tonic) has an effect on therapies applied to the population categories, increasing work capacity and optimizing health (9). The motor skills of children with autism spectrum disorder (ASD) (8-10 years) in Brazil are studied by (10). The more severe the ASD, the greater the deficit in motor skills, and the use of drugs amplifies these manifestations. Positive associations are identified between motor skills and involvement in physical education lessons, respectively with independence in daily activities. The use of physical activities is important for the active lifestyle, the increase of the motor abilities and the quality of life of these groups, ensuring also the widening of the socializing sphere $(11,12)$. The formation of healthy behaviors (related to exercise and nutrition) from an early age are very important in adulthood (13). Anatomical dysfunctions can occur in people with various disabilities, which require recovery processes $(14,15)$.

Movement games stimulates thinking, fights sedentary lifestyle, improves psychomotor skills, increases immunity, is accessible, attractive, spontaneous, being an interesting form of active rest. Organized games are more effective than spontaneous ones, the motor actions performed being a natural tendency of children and a form of communication through body language (16-18).

Physical activities based on attractive exercise games or sports games and other forms of exercise associated with sports, leisure and medical recovery are important factors in optimizing children's health and improving their motor skills (19-21).

The time interval in which semi-structured physical activities are practiced for boys with severe intellectual disabilities (age 9.6 years) counts in the value and the stability of the effects (22). Fundamental movement skills are significantly improved after 1 year (program with 5 workouts / week, $60 \mathrm{~min} / \mathrm{session}$ ), not improved on shorter term / 6 months.

The positive effect of outdoor motion games for improving cognitive functions, increasing the level of social adaptation and psycho-emotional states is highlighted by (23), on a group of 40 students from Ukraine, being a good remedy that can be included in adaptive physical education. The paper of (24) highlights that athletes with intellectual disabilities have increased values of psychological well-being and higher self-esteem compared to non-athletes. Athletes without obesity / overweight have a better self-esteem and perception of body image.

The positive effect of motion games on children with intellectual disabilities in Ukraine is supported by (25). Increases in psycho-emotional state, cognitive functions are reported, games being an easy remedy, which excludes medication and can be included in adaptive physical education. The influence of dog-assisted therapy on the psychomotor development of children with mild intellectual disabilities is investigated by (26). The study made on 60 children, 10-13 years old, for 10 months confirmed significant improvements for postural imitation tests.

Lack of physical activity and the onset of obesity are factors that can lead to negative functional changes and the manifestation of osteoarthritis, according to (27), and the specificity of certain performance physical activities (table tennis) can cause problems at the lumbar level (28).

Tests and computer games can successfully measure the values of reaction times (simple, cognitive and to visual stimuli), for students who practice different individual sports (boxing, gymnastics, wrestling, karate, etc.). The investigation of (29) signals better values of the simple reaction for the left hand, and for the complex one for the right hand. The more complex the application used, the more efficient the dominant hand. Computer educational games can improve the psychomotor development of children with educable intellectual disabilities, being a useful tool in special education, in terms of design and interaction (30).

The use of virtual reality technology (VR), based on the use of virtual pink dolphins, in the learning process of children with autism is proposed by (31). Improvements in psychomotor skills are found: direction and hand-eye-coordination.

The growing incidence of children with autism and the daily challenges they face are signaled by (32). In addition to difficult social interactions and poor communication, psycho-motor deficiencies are also present. The importance of nonverbal communication and bodily expressiveness in physical activities is emphasized by (33), as a significant variant of information in sports training (gymnastics). Through the first signaling system, useful also for activities with the mentally handicapped, communication can be optimized, feelings and emotions are expressed more easily, 
because the language / words are more difficult to understand.

Problems of children with autism are reported by (34), which identifies deficiencies in social interaction, communication, stereotypical behavior, limited involvement in physical effort and low level of fitness. The use of playing games (16 sessions $\mathrm{x}$ $60 \mathrm{~min}$ ) generated a significant improvement in motor skills. The study of (35) performed on young people with autism in Istanbul / Turkey (55 cases, aged 6-26 years), involved in inclusive physical activity (for 3 months, with 2 workouts / week, duration of $45 \mathrm{~min}$ ) identify favorable effects on social skills.

\section{Material and method}

The purpose of the research is the verification of the positive effects of the proposed motion games on the psychomotor skills of students who are affected by ID (intellectual disabilities) and / or ASD (autism spectrum disorder). The study started from the finding that, during physical education classes, but also in other teaching activities, when there is play and movement, students assimilate faster. If we capture their attention and create an atmosphere of acceptance and harmony, the education process will be much easier and more enjoyable.

Working hypothesis: By using and rationally adapting a varied complex of structures and motion games, significant improvements of the psychomotor elements can be obtained at the level of the studied experiment group.

\section{Participants}

The investigated subjects are 5 cases ( 4 boys and a girl, aged 10-11) from the Ion Teodorescu Special Vocational School in Slobozia / Ialomița, with problems related to ASD and ID, which are reflected in behavioral disorders and psychomotor instability, which generates difficulties in adapting to the teaching process. They participated in activities based on different motion games, with various influences on motor behavior and elements of psychomotor skills: attention, coordination, insight, memory, tactile sense, etc. Their results were related to the performance of a control group - normal subjects ( 6 boys aged 10 years, belonging to Saveni / Ialomița Secondary School). The individual characteristics of the members of the experiment group, related to the level of motor and intellectual development, socialization and the manifested problems are summarized in table 1 .

\section{Procedures}

The research took place between 20.09.202010.03.2021, the physical activities of the subjects in the experiment group focusing on various structures and games with influence on psychomotor skills and intellectual dimension. The rules of academic writing have been followed, according to (36). For reasons related to space, the study can only selectively list some of the variants of games included in the work program:

White, black (memory and reaction time) The game can be played with the players sitting in benches, in the classroom: at the word "WHITE" - they stand up, at the word "BLACK" they sit down

Bouquets (attention) The players move through a running step in a column one or two at a time. At some point, the game leader shouts a number, players must quickly gather in a group of players equal to the number called.

Reverse command - is it ordered to walk slowly, and the group will execute the walk quickly, or the command to raise the right arm is given and everyone raises the left arm.

Rocket (memorizing movements). The teacher performs a series of movements such as: clapping at an accelerated pace, running on the spot, rotating the arms, jumping, squats. The children perform the respective exercises as faithfully as possible.

Relay with circles (orientation, eye-hand coordination, accuracy). In front of each team (2-3 teams) from place to place we stick 3 stakes in the ground. The distance between the stakes will be 7-8 steps. The first player in each team receives 3 circles that he inserts in each stake, from running, and on his return he collects them and hands them to the next player.

Show the alphabet! (insight, memory, tactile sense, hearing) We cutout a number of cards equal to that of the letters of the alphabet. One letter is written on each one and they are shuffled, the called player must order the alphabet of the cards.

Show the sentence (insight, memory) The leader hands them a note containing a sentence. The player must redo the sentence using the cards.

Practice your memory (memory, insight) The leader places 24 different objects on the table and covers the table with a piece of cloth. The players are called, the material is picked up and they are given a minute to memorize as many of the objects on the table as possible. Everyone then writes down on a piece of paper the objects they remember. 
What items are missing ? (memory-insight) After placing 30 objects on the table, the leader gives the players 1 minute to memorize them. Then, the players cover their eyes with their palms, while the leader takes an object from the table. The first player to name the object taken by the leader wins it as a trophy.

Reassembly of the illustration (coordination, insight) Cut an image into 10 unequal parts that are mixed and then handed to the players. The time in which the players manage to assemble the image is timed.

Placement of geometric figures (exercise of tactile sense). Cut 10 triangles, squares, circles, rectangles out of cardboard. The geometric figures are placed in the hand of a player whose eyes were previously covered. The player must recognize the geometric figure just by touching it and place it on the correct pile.

\section{Description of tests:}

The cutout test it is used to test spatial representations, the perception of their forms and structure, and practical intelligence. Structure of the sample:

A) A support provided with three different configurations ( 3 cutouts hence the name): square, trapezoid, circle.

B) Square configuration subassemblies (4 figures)

C) Circle configuration subassemblies (5 figures)

D) Trapezoidal configuration subassemblies figures)

The task of the subject is to reconstruct the circlesquare-trapezoid configurations, using the subassemblies (B), (C), (D).

The cutout test is applied individually, with imposed times or with free time (until the subject finishes the test). It usually starts with a square and ends with a circle.

Cohs cubes test $(37,38)$ it is used to test the spatial factor of intelligence, nonverbal cognitive skills. The set consists of several variously colored cubes and in different configurations. By combining several cubes, 10 configurations are obtained whose complexity increases from one number to another. The configuration model is given in the task cards. The task of the subject is to build the 10 configurations, using the cubes and reproducing the pattern of the task cards shown. The test of Cohs cubes is applied individually and the time elapsed for the execution of each configuration is recorded, if it is performed within the time limit. Due to the low intelligence of the subjects, we used the task cards with configurations 0 and 2 .

Attention flexibility test: This game takes place in the gym or on the field. Each corner of the room or field will be named a color. Players must also remember when announcing a color by the teacher, to run to that corner. Those who hesitate or make a mistake will be penalized. Methodical hints: to create surprises, other colors besides those assigned to the corners can be called. For small classes, the corners can be called animals or birds. 10 tries are awarded and the number of successes and failures is recorded separately.

The statistical - mathematical analysis: Due to the low number of subjects in both groups, nonparametric (rank-based) procedures for calculating the differences between groups were required for the initial and final tests (Mann-Whitney U test) and the Wilcoxon test (for the data pairs in the experiment group) (39-42). The control group had a single data set, to which the results of the experiment group were reported for both tests. The central tendency indicators (arithmetic mean) were represented graphically to facilitate a better understanding of the dynamics of group performance, being also presented graphs with individual test performance. The statistical calculation was performed using the IBM SPSS software vers. 24 .

\section{Results}

The data of the average values for the initial and final tests at the level of the experimental group and those of the control group are represented graphically in fig. 1. It is observed that the control group has values higher than the two measurements of the experiment group applied to the whole battery of tests (in the Cohs test and in the Cutout test normal subjects solve the drawn tasks faster / therefore shorter times, and the flexibility test of attention have a higher number of successful attempts, complemented by a lower number of errors)

Table 2 expresses the results of the nonparametric Wilcoxon test (in pairs) at the level of the experiment group. It is observed that all values of $\mathrm{Z}$ are related to thresholds $\mathrm{P}<0.05$, so the progress after the implementation of game-based activities is significant, which demonstrates the usefulness of the proposed programs, based on psychomotor 
structures and games. Graphs 2 and 3 show the individual values of the 5 subjects in the experiment group for the initial and final tests, respectively, being able to notice the heterogeneity of the results especially at the Cohs test and the relatively close values for the cutout test and attention flexibility.

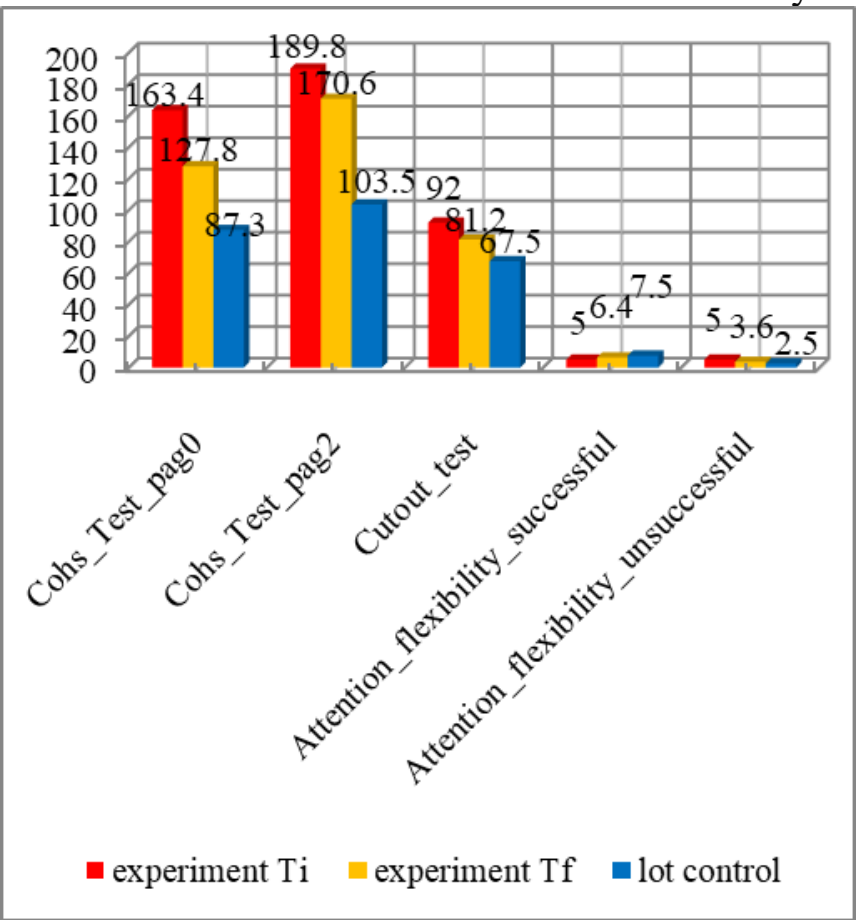

Fig. 1 - Average values in tests for independent groups

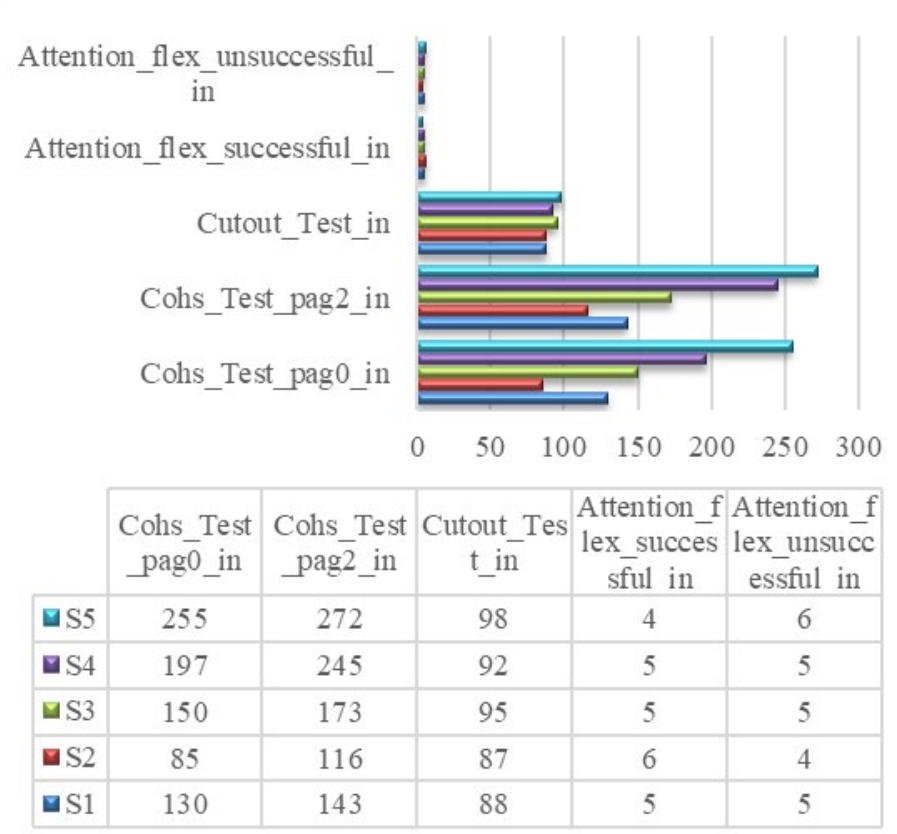

$\square \mathrm{S} 5 \square \mathrm{S} 4 \square \mathrm{S} 3 \square \mathrm{S} 2 \square \mathrm{S} 1$

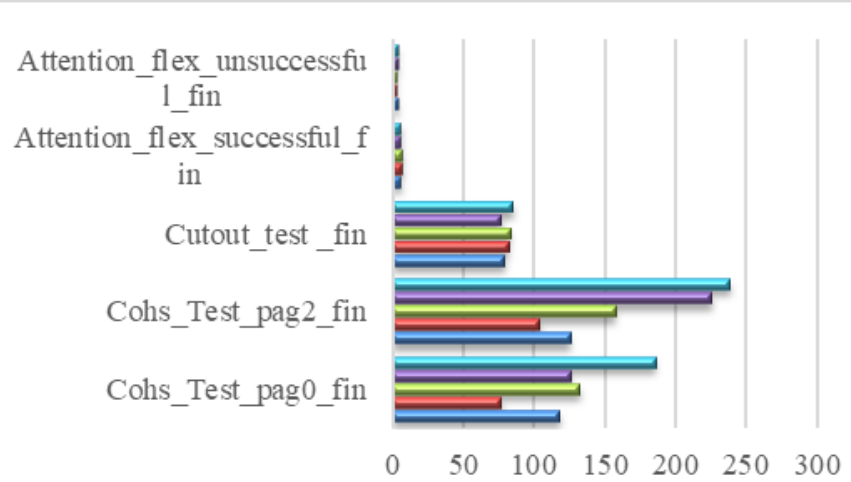

\begin{tabular}{|c|c|c|c|c|c|}
\hline & $\begin{array}{l}\text { Cohs_Test } \\
\text { pag0_fin }\end{array}$ & $\begin{array}{l}\text { Cohs_Test } \\
\text { pag2_fin }\end{array}$ & $\begin{array}{l}\text { Cutout_tes } \\
t \text { _fin }\end{array}$ & $\begin{array}{l}\text { Attention_ } \\
\text { flex_succe } \\
\text { ssful_fin }\end{array}$ & $\begin{array}{l}\text { Attention } \\
\text { flex_unsuc } \\
\text { cessful_fin }\end{array}$ \\
\hline 四5 & 186 & 239 & 85 & 6 & 4 \\
\hline - S4 & 126 & 226 & 77 & 6 & 4 \\
\hline$\square \mathrm{S} 3$ & 132 & 158 & 83 & 7 & 3 \\
\hline$\square \mathrm{S} 2$ & 77 & 104 & 82 & 7 & 3 \\
\hline$\square \mathrm{S} 1$ & 118 & 126 & 79 & 6 & 4 \\
\hline
\end{tabular}

$\square \mathrm{S} 5 \square \mathrm{S} 4 \square \mathrm{S} 3 \boldsymbol{\nabla} 2 \square \mathrm{S} 1$

Fig. 3 - Individual values for the experimental group at final testing

Tables 3 and 4 show the results of the nonparametric test Mann-Whitney U (independent samples) at the level of initial and final tests. It is observed at the initial testing that the control group has statistically significantly higher results than the control group, all values of $Z$ correspond to significance thresholds $\mathrm{P}<0.05$, so it is obvious that the reported disabilities have repercussions on the performance of the experimental group. Even if the comparison of the results between the groups for the final test shows that there are samples where the differences are no longer significant / $\mathrm{Z}$ values correspond to thresholds $\mathrm{P}>0.05$ (this aspect confirming the progress in the experiment group), the values of the control group remain better at the whole set of tests and even significantly better for the Cohs Test pag2 and the Cutout Test.

Graph 4 shows the dynamics of individual test values for the 6 members of the control group. It is observed that even in the case of subjects without the reported disabilities, there are still obvious variations in test performance.

Fig. 2 - Individual values for the experimental group at initial testing 


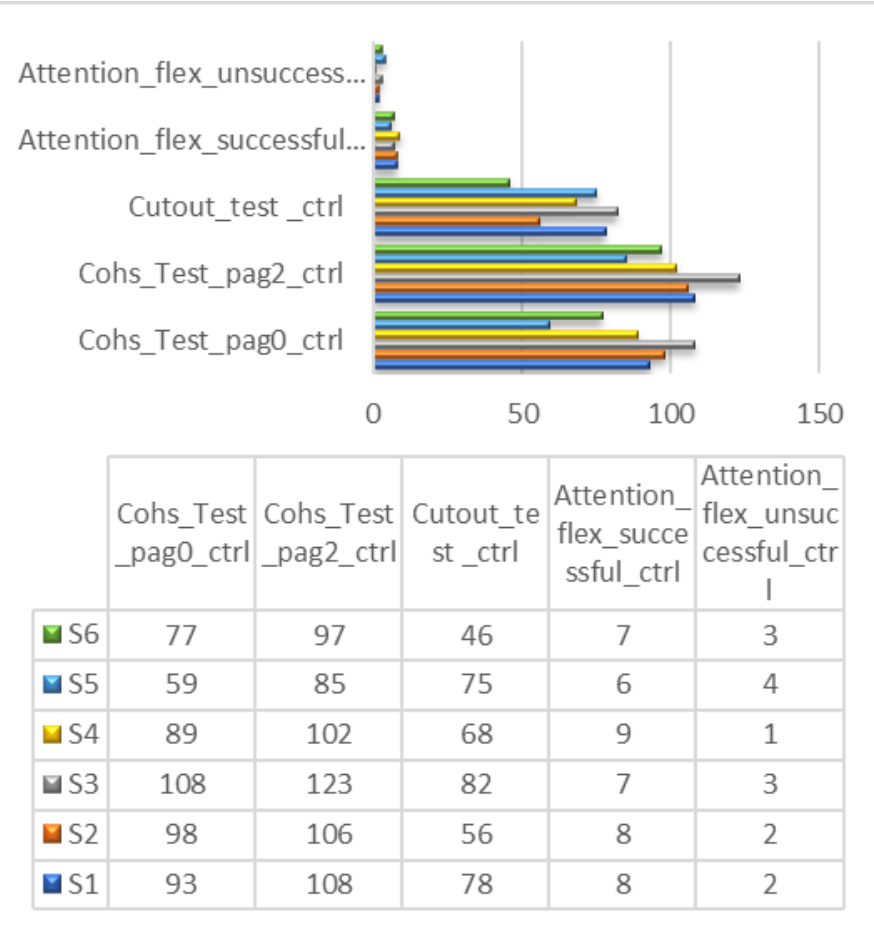

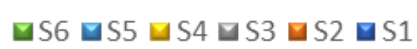

Fig. 4 - Individual values for the control group

\section{DISCUSSION}

The specialized literature presents numerous researches that are directly related to our topic. The study of (43) identifies the positive effects of regular sports training proposed by the Integrated Department of Athletes with Disabilities, for children with autism (12 boys involved 13 weeks / 3 weekly sessions / 1 hour / session), through various programs of agility, speed, strength, coordination and balance. Bruininks-Oseretsky tests indicate significant accumulation / progress for the skills tested, so regular training will improve motor skills for those with autism. Activities focused on psychomotor development, games and individual sports are recommended.

Motor skills of locomotion and control of objects, for children with mild intellectual disabilities in the Czech Republic (114 cases with an average age of 10 years) are studied by (44). Even for running, jumping, throwing, poorer results are obtained, with major individual differences. Only some children with intellectual disabilities (ID) have motor results similar to normal ones, but in most cases this aspect is refuted, so the development of motor skills in children with ID is a priority to support their inclusion in school.
The effectiveness of psychomotor intervention programs (PIP) on children with autism (autism spectrum disorder) is studied by (45). The effects of the applied program (10 weeks, 3 times / week, focused on the body scheme, spatial and temporal component) on the studied group (12 children, aged 5.48 years) improved the performance of psychomotor tests, its use being recommended in the school curriculum.

Problems with static balance and motor development in children with intellectual disabilities are reported by (46). The use of psychomotor education programs for children aged 8-12 years (16 weeks, 2 workouts / week, duration of 45 minutes) significantly improved the performance at static balance, thus contributing to an active and healthy lifestyle.

The use of football as a mean of improving motor skills for children with autism (characterized by limited motor and social skills and difficult learning) is analyzed by (47). The use of football structures (24 sessions $\mathrm{x} 1$ hour) has favorable results on psychomotor behavior and forms healthy sports habits. The usefulness of gymnastic exercises on autistic children in Iran (45 cases, 4-12 years) in the autism center in Isfahan (applied 24 weeks, 2 days / week, $45 \mathrm{~min} / \mathrm{session}$ ) is confirmed by the study of (48). Significant improvements are achieved in total motor skills, ball skills, static and dynamic balance, but without clear progress in manual dexterity tests.

The usefulness of the game of hemsball (based on passing a ball in pairs, by throwing it in a circle on the ground) in improving motor skills for children with moderate and mild intellectual disabilities (12-16 years) is reported by (49). The study on 50 subjects aged 12-16 in Turkey who used the hemsball program (12 weeks x 3 days / week x 1 hour / session) generated significant improvements in hand coordination, balance and bilateral coordination, with greater progress being reported in those with moderate intellectual disabilities.

The promotion of technological progress through the use of LEAP Motion Technology and Psychology - in the detection of hand movements, for the analysis of the level of neuro-development and neurological and cognitive disorders is done by (50). The analyzed sources demonstrate the usefulness of this system for autistic disorders, ADHD, in psychomotor and social rehabilitation, in facilitating learning in different contexts. 
The use of a mechatronic training KIT has positive effects on the psychomotor skills for the palm grasp, the rotation of the fist joint and the eyehand coordination, through a study performed on 6 children with autism (age 4-9 years). Similar results are obtained by using a robot and manipulating it with a joystick, for learning the concept of directions of movement and palmar grasp (51). The use of multisensory virtual games (with manipulation of objects in three dimensions) is proposed by (52) to limit the specific manifestations of ADHD (attention deficit hyperactivity disorder). For the investigated subjects (7-12 years), who found it difficult to maintain voluntary attention for academic and daily activities, there is an increase in the ability to focus and stimulate learning processes.

The use of controlled video games (based on the kinect V2 sensor) is useful in teaching elementary school children (4 cases with intellectual disabilities), with the skill of washing hands, their parents being satisfied with the results of its implementation, according to (53). The use of augmented reality games (AR / augmented reality game) for high school students with intellectual disabilities has improved the skills of subjects related to the use of a banking ATM (automated teller machine), teachers considering it effective in terms of results (54).

The positive effect of motion-based learning games (Kinect) for children with special educational needs is identified by (55). Due to the combination of cognitive and physical tasks, they generate increased academic performance, improved cognitive and motor skills, being recommended to be integrated into the educational process.

The need to expand the notions related to health and physical activities, in order to generate proactive attitudes related to involvement in physical effort is signaled by (56), and significant differences in parameters related to body composition (BMI, obesity, muscle mass, etc.) between active and semiactive students are highlighted by (57).

A review of the scientific literature on the effectiveness of Serious Games / SGs (based on video games with educational effects) as a way of learning for people with different stages of intellectual disabilities is made by (58). This variant needs to be adapted to individual needs. The effectiveness of Serious Games with psychometric properties is also experimented by (59). They achieve obvious improvements in cognitive abilities, focusing of visual attention and motivation on a group of 44 students (6-16 years), with ADHD and learning disorders, by implementing a program of 28 sessions $\times 28$ weeks $\times 10$ minutes, based on 10 games for multiple intelligences. The importance of Serious Games, based on software technologies, for children with autism is also supported by (60), through their educational efficiency, as communication therapy, improvement of social behavior and as psychomotor treatment. The positive effects of Serious Games on students with deficient attention, memory and poor motor control, with mental or developmental disabilities, compared to standard methods are highlighted by (61). The efficiency of Serious Games on people with intellectual disabilities and those with autism spectrum (characterized by problems of social, emotional and communication behavior, even if some autistic people have high intellectual availability and others have cognitive disabilities) is also reported by $(62,63)$. Technological advances (software and computer games) are solutions to improve these problems, depending on the deficiencies found: literacy, daily activities, language, psychomotor skills, etc., teachers and specialists in special education confirm their value and usefulness.

\section{CONCLUSIONS}

The obtained results confirm the working hypothesis, so the use of the structures and games proposed in the program contributes to a significant improvement of the psychomotor and intellectual performances of students with intellectual disabilities and autism spectrum. Despite all these improvements, they cannot match the benchmarks of children without problems in the same age group. A limitation of the study is the small number of subjects included in the study, which does not allow the generalization of the results. Another limitation is the non-use of Serious Games variants, often used and analyzed in some mentioned studies, this aspect being a future research direction, in order to see their efficiency in comparison with the classic training and recovery variants.

\section{Declaration of conflict of interests}

There is no conflict of interest for any of the authors regarding this paper.

\section{Informed consent}

The investigated subjects and legal guardians were informed about the purpose and methodology of the study presented, expressing their agreement to the 
processing and publication of the results of the current study, in compliance with the rules on personal data protection.

\section{Author contribution}

The authors of this article have equal contribution and equal rights over it.

Table 1 - Analysis of the individual defining particularities for the experiment group

\begin{tabular}{|c|c|c|c|}
\hline $\begin{array}{l}\text { Subject } \\
\text { /gender }\end{array}$ & Ages & Diagnostic & Psychic, motor and behavioral characteristics \\
\hline $\begin{array}{l}\text { M.E. } \\
\text { /M }\end{array}$ & 11 & $\begin{array}{l}\text { Autism spectrum } \\
\text { disorder and mental } \\
\text { retardation }\end{array}$ & $\begin{array}{l}\text { The learning process is severely affected due to mental retardation and autism } \\
\text { spectrum disorder. Motor coordination is good, and the body scheme was mastered. } \\
\text { The dominant laterality is right. Fine and coarse motor skills are affected. Space- } \\
\text { temporal orientation is difficult to achieve. Operates with simple notions and } \\
\text { understands cause-effect relationships only in terms of simple life situations. The } \\
\text { thinking is slow, in the operational-concrete stage. The memory is long lasting, but } \\
\text { it stores mechanically. The language is medium developed, and the oral expression } \\
\text { is grammatically incorrect. The student has attention disorders, but with help he } \\
\text { remains stable in the task and completes it. He participates in activities unequally, } \\
\text { fluctuating, but if he is kept in the task with motivations or rewards he manages to } \\
\text { complete all the work tasks. As a social relationship is a sociable type, but with low } \\
\text { resistance to frustration. }\end{array}$ \\
\hline $\begin{array}{l}\text { C.M. } \\
\text { /F }\end{array}$ & 11 & $\begin{array}{l}\text { Epilepsy and mental } \\
\text { retardation }\end{array}$ & $\begin{array}{l}\text { The student comes to school uncared for. She has a tendency to steal and is mean to } \\
\text { her classmates. She lies a lot at school, but also at home. She has a poor thinking, } \\
\text { with training tendencies, he can hardly distinguish the essential. She generally learns } \\
\text { with some interest, trying to outperform her colleagues. She can keep her } \\
\text { concentration and attention but only if she is closely guided. Psychomotor } \\
\text { development: motor coordination is good. The body scheme is mastered. Right } \\
\text { dominant laterality. Fine and coarse motor skills are affected. She has moments } \\
\text { when she loses her balance. The space-temporal orientation is achieved at a low } \\
\text { level. }\end{array}$ \\
\hline $\begin{array}{l}\text { A.A. } \\
\text { /M }\end{array}$ & 10 & $\begin{array}{l}\text { Highly functional } \\
\text { autistic, but with } \\
\text { emotional disorders. }\end{array}$ & $\begin{array}{l}\text { He is a disciplined student, enjoying the sympathy of his colleagues. The learning } \\
\text { process is done at a very good level for the requirements of the special school. } \\
\text { Psychomotor development: motor coordination is good. The body scheme is } \\
\text { mastered. Right dominant laterality. Fine and coarse motor skills are slightly } \\
\text { affected. The space-temporal orientation is good. Thinking is specific to the stage of } \\
\text { concrete operations. Understands complex notions and cause-effect relationships. } \\
\text { The memory is long lasting. It is capable of abstraction and generalization. } \\
\text { Vocabulary is well developed. Shows will and interest in school activities. In } \\
\text { relationships with colleagues and teachers he is an example student. }\end{array}$ \\
\hline $\begin{array}{l}\text { B.S. } \\
/ \mathrm{M}\end{array}$ & 10 & $\begin{array}{l}\text { Autism spectrum } \\
\text { disorder and severe } \\
\text { developmental delay }\end{array}$ & $\begin{array}{l}\text { The learning process is severely affected due to mental retardation in development. } \\
\text { Motor coordination is severely impaired. The body scheme is mastered. Dominant } \\
\text { left laterality. Fine and coarse motor skills are affected. The space-temporal } \\
\text { orientation is achieved with an imbalance. Thinking is specific to the pre-operational } \\
\text { stage, understands simple notions. The memory is short-lived, it forgets very } \\
\text { quickly. Vocabulary is low. He has attention disorders, his concentration is low, he } \\
\text { gets tired quickly. Load stability is fluctuating and volume is low. It is difficult to } \\
\text { train in tasks, but if he receives a reward he participates. The student is shy, not very } \\
\text { communicative. He has moments when he can't control himself and he becomes } \\
\text { aggressive for those around him due to seemingly minor reasons. }\end{array}$ \\
\hline $\begin{array}{l}\text { C.C. } \\
\text { /M }\end{array}$ & 11 & $\begin{array}{l}\text { Slightly delayed } \\
\text { development }\end{array}$ & $\begin{array}{l}\text { Motor coordination is good. The body scheme is mastered. Right dominant } \\
\text { laterality. Fine and coarse motor skills are within good limits. The space-temporal } \\
\text { orientation is almost normal. He understands complex notions and can handle } \\
\text { himself at home for a few hours. The memory is long lasting. The vocabulary is rich } \\
\text { and is expressed clearly and correctly. It does not show attention disorders, it can } \\
\text { concentrate quite well, it is stable. He is active in lessons, showing an intrinsic } \\
\text { motivation. He is sociable and behaves appropriately. }\end{array}$ \\
\hline
\end{tabular}


Table 2 / Wilcoxon ${ }^{\mathrm{a}}$ nonparametric test results (pairs) / experimental group $(\mathrm{N}=5)$

\begin{tabular}{|c|c|c|c|c|c|c|}
\hline Test & Mean & $\begin{array}{c}\text { Std. } \\
\text { Deviation }\end{array}$ & $\begin{array}{c}\text { Std. Error } \\
\text { Mean }\end{array}$ & $\begin{array}{c}\text { Mean } \\
\text { Difference }\end{array}$ & $\mathbf{Z}$ & $\begin{array}{c}\text { Sig. } \\
\text { (2-tailed) }\end{array}$ \\
\hline Cohs_Test_pag0_initial & 163.4000 & 65.1175 & 29.1214 & \multirow{2}{*}{35.6000} & \multirow{2}{*}{$-2.023^{b}$} & \multirow{2}{*}{0.043} \\
\hline Cohs_Test_pag0 fin & 127.8000 & 39.0025 & 17.4424 & & & \\
\hline Cohs_Test_pag2_initial & 189.8000 & 66.5635 & 29.7681 & \multirow{2}{*}{19.2000} & \multirow{2}{*}{$-2.023^{b}$} & \multirow{2}{*}{0.043} \\
\hline Cohs_Test_pag2_fin & 170.6000 & 59.8565 & 26.7686 & & & \\
\hline Cutout_Test_initial & 92.0000 & 4.6368 & 2.0736 & \multirow{2}{*}{10.8000} & \multirow{2}{*}{$-2.023^{b}$} & \multirow{2}{*}{0.043} \\
\hline Cutout_Test_final & 81.2000 & 3.1937 & 1.4282 & & & \\
\hline Attention_flexibility_successful_initial & 5.0000 & 0.7071 & 0.3162 & \multirow{2}{*}{-1.4000} & \multirow{2}{*}{$-2.070^{c}$} & \multirow{2}{*}{0.038} \\
\hline Attention_flexibility_successful_final & 6.4000 & 0.5477 & 0.2449 & & & \\
\hline Attention_flexibility_unsuccessful_initial & 5.0000 & 0.7071 & 0.3162 & \multirow{2}{*}{1.4000} & \multirow{2}{*}{$-2.070^{\mathrm{b}}$} & \multirow{2}{*}{0.038} \\
\hline Attention_flexibility_unsuccessful_final & 3.6000 & 0.5477 & 0.2449 & & & \\
\hline
\end{tabular}

Table 3 / Mann-Whitney U nonparametric test results (independent samples) / initial testing / control group ( $\mathrm{N}=6$ ), experimental

\begin{tabular}{|c|c|c|c|c|c|c|c|}
\hline Test & Lot & Mean & $\begin{array}{c}\text { Std. } \\
\text { Deviation }\end{array}$ & \begin{tabular}{|c|}
$\begin{array}{c}\text { Std. Error } \\
\text { Mean }\end{array}$ \\
\end{tabular} & \begin{tabular}{|c|} 
Mean \\
Difference \\
\end{tabular} & $\mathbf{Z}$ & $\begin{array}{c}\text { Sig. } \\
\text { (2-tailed) }\end{array}$ \\
\hline \multirow{2}{*}{ Cohs_Test_pag0 } & control & 87.3333 & 17.2356 & 7.0364 & \multirow{2}{*}{-76.0666} & \multirow{2}{*}{-2.008} & \multirow{2}{*}{0.045} \\
\hline & experiment & 163.4000 & 65.1175 & 29.121 & & & \\
\hline \multirow{2}{*}{ Cohs_Test_pag2 } & control & 103.5000 & 12.5976 & 5.1429 & \multirow{2}{*}{-86.3000} & \multirow{2}{*}{-2.556} & \multirow{2}{*}{0.011} \\
\hline & experiment & 189.8000 & 66.5635 & 29.7681 & & & \\
\hline \multirow{2}{*}{ Cutout_test } & control & 67.5000 & 13.9391 & 5.6906 & \multirow{2}{*}{-24.5000} & \multirow{2}{*}{-2.739} & \multirow{2}{*}{0.006} \\
\hline & experiment & 92.0000 & 4.6368 & 2.0736 & & & \\
\hline \multirow{2}{*}{ Attention_flexibility_successful } & control & 7.5000 & 1.0488 & 0.4281 & \multirow{2}{*}{2.5000} & \multirow{2}{*}{-2.690} & \multirow{2}{*}{0.007} \\
\hline & experiment & 5.0000 & 0.7071 & 0.3162 & & & \\
\hline \multirow{2}{*}{ Attention_flexibility_unsuccessful } & control & 2.5000 & 1.0488 & 0.4281 & \multirow{2}{*}{-2.5000} & \multirow{2}{*}{-2.690} & \multirow{2}{*}{0.007} \\
\hline & experiment & 5.0000 & 0.7071 & 0.3162 & & & \\
\hline
\end{tabular}

Table 4 / Mann-Whitney U nonparametric test results (independent samples) / final testing / control group ( $\mathrm{N}=6$ ), experimental

\begin{tabular}{|c|c|c|c|c|c|c|c|}
\hline Test & Lot & Mean & $\begin{array}{c}\text { Std. } \\
\text { Deviation }\end{array}$ & \begin{tabular}{|c|}
$\begin{array}{c}\text { Std. Error } \\
\text { Mean }\end{array}$ \\
\end{tabular} & \begin{tabular}{|c|} 
Mean \\
Difference \\
\end{tabular} & $\mathbf{Z}$ & $\begin{array}{c}\text { Sig. } \\
\text { (2-tailed) }\end{array}$ \\
\hline \multirow{2}{*}{ Cohs_Test_pag0 } & control & 87.3333 & 17.2356 & 7.0364 & \multirow{2}{*}{-40.4666} & \multirow{2}{*}{-1.921} & \multirow{2}{*}{0.055} \\
\hline & experiment & 127.8000 & 39.0025 & 17.4424 & & & \\
\hline \multirow{2}{*}{ Cohs_Test_pag2 } & control & 103.5000 & 12.5976 & 5.1429 & \multirow{2}{*}{-67.1000} & \multirow{2}{*}{-2.191} & \multirow{2}{*}{0.028} \\
\hline & experiment & 170.6000 & 59.8565 & 26.7686 & & & \\
\hline \multirow{2}{*}{ Cutout_test } & control & 67.5000 & 13.9391 & 5.6906 & \multirow{2}{*}{-13.7000} & \multirow{2}{*}{-2.104} & \multirow{2}{*}{0.035} \\
\hline & experiment & 81.2000 & 3.1937 & 1.4282 & & & \\
\hline \multirow{2}{*}{ Attention_flexibility_successful } & control & 7.5000 & 1.0488 & 0.4281 & \multirow{2}{*}{1.1000} & \multirow{2}{*}{-1.824} & \multirow{2}{*}{0.068} \\
\hline & experiment & 6.4000 & 0.5477 & 0.2449 & & & \\
\hline \multirow{2}{*}{ Attention_flexibility_unsuccessful } & control & 2.5000 & 1.0488 & 0.4281 & \multirow{2}{*}{-1.1000} & \multirow{2}{*}{-1.824} & \multirow{2}{*}{0.068} \\
\hline & experiment & 3.6000 & 0.5477 & 0.2449 & & & \\
\hline
\end{tabular}




\section{References}

1. Aharoni H. Psychomotor characteristics and implications for programming and motor intervention. International Journal of Adolescent Medicine and Health [Internet]. 2005 Jan [cited 2021 Sep 1];17(1). Available from: https://www.degruyter.com/document/doi/10.1515/ IJAMH.2005.17.1.33/html

2. Sherrill C. Adapted Physical Activity, Recreation and Sport: Crossdisciplinary and Lifespan. Fifth Edition. WCB/McGraw Hill, 2460 Kerper Blvd; 1998.

3. Jankauskiene R, Baceviciene M, Pajaujiene S, Badau D. Are Adolescent Body Image Concerns Associated with Health-Compromising Physical Activity Behaviours? International Journal of Environmental Research and Public Health. 2019 Jan;16(7):1225.

4. Mazzone L, Postorino V, De Peppo L, Fatta L, Lucarelli V, Reale L, et al. Mood symptoms in children and adolescents with autism spectrum disorders. Research in Developmental Disabilities. 2013 Nov 1;34(11):3699-708.

5. Gvozdjáková A, Kucharská J, Ostatníková D, Babinská K, Nakládal D, Crane FL. Ubiquinol Improves Symptoms in Children with Autism. Oxidative Medicine and Cellular Longevity. 2014 Feb 23;2014:e798957.

6. Maïano C, Hue O, April J. Effects of motor skill interventions on fundamental movement skills in children and adolescents with intellectual disabilities: a systematic review. Journal of Intellectual Disability Research. 2019;63(9):116379.

7. Maïano C, Hue O, April J. Fundamental movement skills in children and adolescents with intellectual disabilities: A systematic review. Journal of Applied Research in Intellectual Disabilities. 2019;32(5):1018-33.

8. Movahedi Y, Esmaeili S. Effectiveness of physical exercise on the growth of the Psycho- motor skills in children with learning disorder. Shenakht journal of psychology \& psychiatry. 2015 Dec 10;2(3):16-28.

9. Munteanu C, Cinteză D. Cercetarea ştiinţifică a factorilor naturali terapeutici. Bucureşti: Editura Balneară; 2011.

10. Kruger GR, Silveira JR, Marques AC. Motor skills of children with autism spectrum disorder. Rev bras cineantropom desempenho hum [Internet]. 2019 Oct 17 [cited 2021 Sep 1];21. Available from: http://www.scielo.br/j/rbcdh/a/KhP3n5434Rrwy5t D95NWngH/?lang=en\& format $=$ html

11. Gheorghiu A. Metodica implementării mijloacelor din fitness în procesul de integrare socială a femeilor de 35-45 ani. Ştiinţa Culturii Fizice. 2014;4(20):81-8.

12. Liuşnea $C$ Ștefan. CONSIDERATIONS ON THE HISTORICAL DEVELOPMENT OF THE LOISIR CONCEPT IN THE EUROPEAN SPACE. International Multidisciplinary Scientific Conference on the Dialogue between Sciences \& Arts, Religion \& Education. 2018;2(2):251-60.

13. Mihai C, Elena V. A comparative approach on the impact of diet and physical activity on young people between 19 and 26 years. Balneo and PRM Research Journal. 2021 Sep 3; Vol.12:5.

14. Luca C, Andritoi D, Fuior R, Zaharia D, Onu I, Corciova C. Autonomic dysfunction and peripheral nerve involvement in patients with Parkinson's disease. Balneo. 2019 Feb 20;10(1):55-61.

15. Onu I, Matei D, Galaction A. Efficacy of intraarticular hyaluronic acid injections in the rehabilitation programme of Knee Osteoarthritis. Munteanu C, editor. BALNEO. 2019 Sep 3;10(Vol.10, No.3):225-30.

16. Badau D, Badau A. Activități ludice în educație fizică și adaptate în kinetoterapie [Internet]. Targu Mureș: Editura University Press; 2013 [cited 2021 Aug 31]. Available from: https://scholar.google.ro/citations?view_op=view citation\&hl=ro\&user $=$ r97LXTIAAAAJ\&cstart $=20$ \&pagesize $=80 \&$ citation for view $=$ r97LXTIAAA AJ:XiSMed-E-HIC

17. Dobrescu T. Dimensiuni ale comunicării prin limbajul corpului [Internet]. Editura Tehnopress; 2006 [cited 2021 Aug 31]. 169 p. Available from: https://scholar.google.ro/citations?view_op=view_ citation\&hl=ro\&user $=8 \mathrm{yWISdMAAAAJ} \&$ citation for_view=8yWISdMAAAAJ:-f6ydRqryjwC

18. Mocanu GD. Loisir / Activități motrice de timp liber [Internet]. Galati: Galati University Press; 2018 [cited 2020 Oct 13]. Available from: http://arthra.ugal.ro/handle/123456789/6293

19. Munteanu C, Munteanu D. Thalassotherapy today. BALNEO. 2019 Dec 10;10(Vol 10 No. 4):440-4.

20. Savu V-C. Influence of the Preparation Games on Increasing Efficiency in the Training of the School Representative Soccer Team. GYMNASIUM. 2019 Jun 24;XIX (1):161-76.

21. Waheed N, Amir M, Noureen R, Nawaz S, Zaidi Syeda Wajeeha R. EFFECTIVENESS OF CERVICAL MANUAL MOBILIZATION TECHNIQUES VERSUS STRETCHING EXERCISES FOR PAIN RELIEF IN THE MANAGEMENT OF NECK PAIN. Balneo and PRM Research Journal. 2021 Sep 1;12(3):261-4.

22. Zhang L, Zhu X, Haegele JA, Wang D, Wu X. Effects of a one-year physical activity intervention on fundamental movement skills of boys with 
severe intellectual disabilities. Research in Developmental Disabilities. 2021 Jul 1;114:103980.

23. Круцевич ТЮ, Пангелова НЄ, Кузнецова Л, Марченко О, Трачук С, Пангелова МБ, et al. Effect of motion games on the psychoemotional state of children with intellectual disabilities. 2020 [cited 2021 Sep 1]; Available from: http://ephsheir.phdpu.edu.ua/handle/8989898989/4 738

24. Pan C-C. Examination of associations of physical self-concept of athletes with intellectual disabilities. 2016 Dec 30 [cited 2021 Sep 1]; Available from: https://wuir.tdl.org/handle/11274/9623

25. Tetiana K, Natalia P, Larysa K, Oksana M, Sergii T, Natalia P, et al. Effect of Motion Games on the Psychoemotional State of Children with Intellectual Disabilities. 2020 Mar [cited 2021 Sep 1]; Available from: http://reposit.unisport.edu.ua/handle/787878787/2911

26. Wolan-Nieroda A, Dudziak J, Drużbicki M, Pniak B, Guzik A. Effect of Dog-Assisted Therapy on Psychomotor Development of Children with Intellectual Disability. Children. 2021 Jan;8(1):13.

27. Gherghel R, Iordan D-A, Mocanu M-D, Onu A, Onu I. Osteoarthritis is not a disease, but rather an accumulation of predisposing factors. A systematic review. Balneo and PRM Research Journal 2021 Sep ; Vol.12, No.3:10.

28. Iordan D-A, Mocanu M-D, Mereuta C. Topspin's Influence on the Spine in Female Juniors III in Table Tennis. BRAIN Broad Research in Artificial Intelligence and Neuroscience. 2021 Feb 15;11(4Sup1):125-43.

29. Badau D, Baydil B, Badau A. Differences among Three Measures of Reaction Time Based on Hand Laterality in Individual Sports. Sports. 2018 Jun;6(2):45.

30. Karal H, Kokoç M, Ayyıldız U. Educational computer games for developing psychomotor ability in children with mild mental impairment. Procedia - Social and Behavioral Sciences. 2010 Jan 1;9:996-1000.

31. Lu A, Chan S, Cai Y, Huang L, Nay ZT, Goei SL. Learning through VR gaming with virtual pink dolphins for children with ASD. Interactive Learning Environments. 2018 Aug 18;26(6):71829.

32. Moorthy RS, Iyer K, Krishnan RH, Pugazhenthi S. Enhancement of psychomotor skills in children with autism spectrum disorder by employing a mechatronic training kit. Paladyn, Journal of Behavioral Robotics. 2019 Jan 1;10(1):1-13.

33. Dobrescu T. The Role of Non-verbal
Communication in the Coach-athlete Relationship. Procedia - Social and Behavioral Sciences. 2014 Sep;149:286-91.

34. Hassani F, Shahrbanian S, Shahidi SH, Sheikh M. Playing games can improve physical performance in children with autism. International Journal of Developmental Disabilities. 2020 Apr 15;0(0):1-8.

35. Nalbant S. Effects of Participation in Inclusive Physical Activity on Social Skills of Individuals with Autism Spectrum Disorder. Journal of Education and Training Studies. 2018 Dec;6(12):255-61.

36. Sandu AŞ. Etică şi deontologie profesională. Iaşi: Lumen; 2012.

37. Amadeus IQ. Test screening IQ - Kohs [Internet]. 2013 [cited 2021 Sep 7]. Available from: https://www.youtube.com/watch?v=xze_9ION-4I

38. Miska Andrea Moreno B. test Cubos de kohs [Internet]. 2018 [cited 2021 Sep 7]. Available from: https://www.youtube.com/watch?v=nWMyMSjTn $\mathrm{Mg}$

39. Ababei R. Metodologia cercetării activităţilor corporale [Internet]. Pim; 2006 [cited 2021 Sep 7]. Available from: https://scholar.google.ro/citations?view_op=view citation $\&$ hl $=$ ro\&user $=\mathrm{XxW}$ 1SPMAAAAJ\&citatio $\mathrm{n}$ for_view $=\mathrm{XxW}$ 1SPMAAAAJ:WF5omc3nYNo $\mathrm{C}$

40. Murariu G. Fizică statistică și computațională Aspecte contemporane si aplicații. Galati: Galați University Press; 2018. 220 p.

41. Murariu G, Munteanu D. Lucrări practice de identificare, modelare şi simulare a proceselor fizice. Galati: Galați University Press; 2018. 20-37 p.

42. Opariuc-Dan C. Statistică aplicată în științele socio-umane. Analiza asocierilor și a diferențelor statistice. Constanța; 2011. 372 p.

43. Akyüz M, Odabas C, Akyüz Ö, Dogru Y, Senel Ö, Tas M, et al. Examination of Effects of Regular Sports Training on Individual Skills in Trainable Children with Autism [Internet]. Vol. 6, Online Submission. 2016 [cited 2021 Sep 1]. Available from: https://eric.ed.gov/?id=ED570874

44. Zikl P, Holoubková N, Karásková H, Veselíková TB. Gross Motor Skills of Children with Mild Intellectual Disabilities. 2013;7(10):7.

45. ElGarhy S, Liu T. Effects of psychomotor intervention program on students with autism spectrum disorder. School Psychology Quarterly. 2016;31(4):491-506.

46. Fotiadou EG, Neofotistou KH, Giagazoglou PF, Tsimaras VK. The Effect of a Psychomotor Education Program on the Static Balance of Children With Intellectual Disability. The Journal 
of Strength \& Conditioning Research. 2017 Jun;31(6):1702-8.

47. López JM, Moreno-Rodríguez R, Alcover C-M, Garrote I, Sánchez S. Effects of a Program of Sport Schools on Development of Social and Psychomotor Skills of People with Autistic Spectrum Disorders: A Pilot Project. Journal of Education and Training Studies. 2017 Aug;5(8):167-77.

48. Rajabi F, Namazizadeh M, Badami R. The Effect of Basic Gymnastics Exercises on Movement Skills of children with autism disorder. Motor Behavior. 2015 Aug 23;7(20):73-88.

49. Işık M, Zorba E. The effects of hemsball on the motor proficiency of students with intellectual disabilities. International Journal of Developmental Disabilities. 2020 Mar 14;66(2):104-12.

50. Colombini G, Duradoni M, Carpi F, Vagnoli L, Guazzini A. LEAP Motion Technology and Psychology: A Mini-Review on Hand Movements Sensing for Neurodevelopmental and Neurocognitive Disorders. International Journal of Environmental Research and Public Health. 2021 Jan;18(8):4006.

51. Moorthy RS, Pugazhenthi S. Teaching Psychomotor Skills to Autistic Children by Employing a Robotic Training Kit: A Pilot Study. Int J of Soc Robotics. 2017 Jan;9(1):97-108.

52. Capelo DC, Sánchez ME, Hurtado JS, Chicaiza DB. Multisensory Virtual Game with Use of the Device Leap Motion to Improve the Lack of Attention in Children of 7-12 Years with ADHD. In: Rocha Á, Guarda T, editors. Proceedings of the International Conference on Information Technology \& Systems (ICITS 2018). Cham: Springer International Publishing; 2018. p. 897906. (Advances in Intelligent Systems and Computing).

53. Kang Y-S, Chang Y-J. Using a motion-controlled game to teach four elementary school children with intellectual disabilities to improve hand hygiene. Journal of Applied Research in Intellectual Disabilities. 2019;32(4):942-51.

54. Kang Y-S, Chang Y-J. Using an augmented reality game to teach three junior high school students with intellectual disabilities to improve ATM use. Journal of Applied Research in Intellectual Disabilities. 2020;33(3):409-19.

55. Kourakli M, Altanis I, Retalis S, Boloudakis M, Zbainos D, Antonopoulou K. Towards the improvement of the cognitive, motoric and academic skills of students with special educational needs using Kinect learning games. International Journal of Child-Computer Interaction. 2017 Jan 1;11:28-39.
56. Badau D, Badau A. Identifying the Incidence of Exercise Dependence Attitudes, Levels of Body Perception, and Preferences for Use of Fitness Technology Monitoring. International Journal of Environmental Research and Public Health. 2018 Dec;15(12):2614.

57. Badau D, Badau A, Trambitas C, Trambitas-Miron D, Moraru R, Stan AA, et al. Differences between Active and Semi-Active Students Regarding the Parameters of Body Composition Using Bioimpedance and Magnetic Bioresonance Technologies. International Journal of Environmental Research and Public Health. 2021 Jan;18(15):7906.

58. Cano AR, García-Tejedor ÁJ, Fernández-Manjón B. A Literature Review of Serious Games for Intellectual Disabilities. In: Conole G, Klobučar T, Rensing C, Konert J, Lavoué E, editors. Design for Teaching and Learning in a Networked World. Cham: Springer International Publishing; 2015. p. 560-3. (Lecture Notes in Computer Science).

59. García-Redondo P, García T, Areces D, Núñez JC, Rodríguez C. Serious Games and Their Effect Improving Attention in Students with Learning Disabilities. International Journal of Environmental Research and Public Health. 2019 Jan;16(14):2480.

60. Noor HAM, Shahbodin F, Pee NC. Serious Game for Autism Children: Review of Literature. 2012;7.

61. Papanastasiou G, Drigas A, Skianis C, Lytras MD. Serious games in K-12 education: Benefits and impacts on students with attention, memory and developmental disabilities. Program. 2017 Jan 1;51(4):424-40.

62. Tsikinas S, Xinogalos S, Satratzemi M. Review on Serious Games for People with Intellectual Disabilities and Autism. In: 10th European Conference on Games Based Learning [Internet]. 2016 [cited 2021 Sep 1]. Available from: https://ruomo.lib.uom.gr/handle/7000/488

63. Tsikinas S, Xinogalos S, Satratzemi M, Kartasidou L. Using Serious Games for Promoting Blended Learning for People with Intellectual Disabilities and Autism: Literature vs Reality. In: Auer ME, Tsiatsos $\mathrm{T}$, editors. Interactive Mobile Communication Technologies and Learning. Cham: Springer International Publishing; 2018. p. 563-74. (Advances in Intelligent Systems and Computing). 